Survey map. This correction is made on the accompanying map.

The party then drove back to Dorking, whence the train was taken to town.

Miss Cadmore acted as Excursion Secretary on this occasion.

\title{
REFERENCES.
}

Geological Survey Map (Old Series), Sheet 8.

Ordnance Map, 6 inch, Sheet 33, S.E., S.W. and N.W.

1875. TOPLEY, W.- "Geology of the Weald." Mem. Geol. Survey.

1893. Boulger, J: S., and LeIGHxon, T.- "On the Lower Greensand Area - . between Wotton and Dorking." Proc. Geol. Assoc., vol, xiii, p. 4 .

1893. Leighton, T.-"Excursion to Abinger." Proc. Geol. Assoc., vol. xiii, p. $16_{3}$.

1895. - - "The Lower Greensand above the Atherfield Clay of East Surrey." Quart. Fourn. Geol. Soc, vol. li, p. Ior.

r896. - "Excursion to Dorking and Leith Hill." Proc. Geol. Assoc. vol. xiv, p. $33 \mathrm{I}$.

\section{REPORT OF AN EXCURSION TO IPSWICH AND THE GIPPING VALLEY.}

Saturday, June 8Th, igtz.

By P. G. H. Boswell, B.Sc., F.G.S.

This Excursion was under the direction of the writer, in conjunction with Mr. G. Slater, F.G.S. The party assembled at Ipswich Station at 1.57 p.m., and consisted of about I 2 members of the Association and some 20 members of the Ipswich and District Field Club.

A special electric car conveyed the party to Bramford Road Terminus, copies of a 6-inch geological map, a r-inch contoured map, and a section across the Gipping Valley being distributed on the way.

Proceeding down the Sproughton Road, a halt was made upon rather high ground at the railway level-crossing, and here Mr. Slater described the normal geological succession in the area to be studied, viz., Upper Chalk, 'Thanet Beds, Woolwich and Reading Series, London Clay, Red Crag, Glacial Sands, Gravels and Loam, and Chalky Boulder Clay. Looking south-eastwards, in the distance the party could see the line-widening operations now being carried out by the G.E. Railway, north-west of Ipswich Station, on the south side of the cutting just before the Norwich and Yarmouth lines diverge. Mr. Slater referred to the section shown on the north side of the cutting in I900-1905, which he 
had carefully worked out and drawn to scale (Proc. Geol. Assoc., vol. $\mathrm{xx}$, plate $\mathrm{v}$, facing $\mathrm{p}$. 192). This was seen in part by the Association on its visit to Ipswich and Claydon in 1907 (op. cit., p. I86). He now exhibited a similarly worked-out section of the beds shown at the new widening. Permissicn had been obtained for the Association to see this, but, unfortunately, the work was nearly finished and the embankment shored up, thus obscuring the beds. He compared the tremendously disturbed mass of strata with the beds in their normal order, the Gipping Valley glacial phenomena being especially illustrated by the contortion, buttressing, over-riding, planing and tearing of the various beds, and the final evidence of torrential flows.

After a short but very interesting discussion, in which the hope was expressed that the new section would be published in the near future, the members proceeded to a pit situated near the Sproughton Road, three-quarters of a mile south-east of Bramford Church. The pit having been overgrown for some years, an excavation had been made for this occasion, and about io $\mathrm{ft}$. of buff-coloured Boulder Clay (which Mr. Slater designates "valley type," as distinct from the deep blue "plateau type") was seen resting fairly evenly upon rather over $5 \mathrm{ft}$. of "Thanet Beds. The section showing in $\mathrm{I}_{72} 2$ was figured by $\mathrm{Mr}$. Whitaker in the Survey Memoir (see references), and the details of the Thanet Beds now seen are-

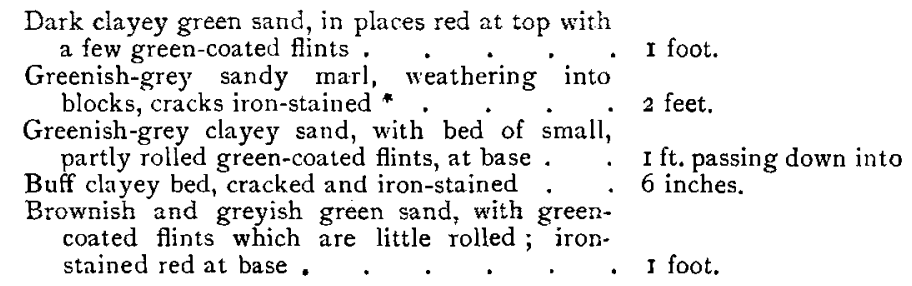

The Thanet Beds were seen resting evenly upon the Chalk, which was also visible forming the floor of the pit. Everything from the Crag to the basement-beds of the Thanets bad been removed before the deposition of the Boulder Clay, and this abbreviated sequence was contrasted with the fuller one seen later on. The opening up of the section was rendered possible by kind permission of Mr. H. W. Mason, of the Manor House, Sproughton, and Mr. I. Fletcher, the occupier. The former gentleman exhibited some derived rocks (igneous, and fossiliferous Jurassic débris) from a gravel pit near the house, showing washed-out material from the Chalky Boulder Clay, and was cordially thanked for his kindness.

Before leaving the pit to proceed to the "Half-way Houses"

* Mr. Whitaker says this resembles the Thanet marl of East Kent. 
excavations off Bramford Road, the writer referred to one or two interesting questions brought out in the course of making a survey for a 6-inch geological map of the district, copies of a part of the map being in the hands of the members. The probability of disturbance of the beds forming the bluff round which the River Gipping winds, and upon the south-east side of which the pit was situated, was shown by, the irregular outcrops of Chalk, Eocene Beds, Boulder Clay, Loam and Gravel, at Hazel Wood, to the north-west of the party's position. It was further pointed out that the glacial sands and gravels (Middle Glacial of the Geological Survey), loams, and boulder clays were part of one series, each often passing into the other, and in many cases the drawing of hard-and-fast boundaries between them was simply introducing artificialities.

The party now set out upon a two-mile walk to the Bramford brickyard and pits, stopping a few minutes, however, at the "Half-way Houses" on the north side of Bramford Road, I/4 mile west of the terminus, to confirm Mr. Slater's figured section ( $o p$. cit., Plate V, facing p. I92) of Chalky-Kimeridgian Boulder Clay ploughing into glacial sand and gravel; the "Kimeridgian " plateau type of boulder clay and its characteristic weathering being particularly observed. The unexpected thickness of $40 \mathrm{ft}$. of glacial sand was recorded in a well at the houses near. On the way members noted a road-cutting in yellowish glacial loam (? a wash from the Boulder Clay), and also several sarsens, whose origin and distribution (and also that of the Hertfordshire conglomerate) in this area were commented upon.

Upon arrival at Grove House the members were met by $\mathrm{Mr}$. Edward Packard, and conducted through the Grove, a veritable botanists' paradise, to the Bramford brickyard (Plate 32.A). The sections exposed here and in the adjacent chalk-pit give the following succession of beds :

DRIFT.

CraG (?)

LONDON Clay.

READING BEDS.
I. Coarse, whitish gravel and sand, resting irregularly on 2 , containing flints and quartzites chiefly

2. Fine, light-coloured sand with thin ferruginous layers, gravelly base

3. Brown and grey laminated clay and loam (Basement-bed of London Clay) .

4. Sandy pebble-bed of black flints 5. Light - coloured whitish sharp sand, current-bedded, especially in upper part, with long lenticular masses of iron-shot grey clay up to $3 \mathrm{ft}$. or more thick, with ironstone nodules at base; here and there a few fints and pebbles $\mathrm{ft}$.

Proc. Geol. Assoc,, Vol. XXIII, Part 4, Igi2.] 
Thanet Beds.

ChaLK.
6. (a.) Clayey sand, olive green but mottled red, $\mathrm{I} \frac{1}{2} \mathrm{ft}$.

(b.) Greenish grey clay, somewhat marly, $3 \mathrm{ft}$.

(c.) Sticky yellowish clay, passing in the south part into a harder bed of cement-like stone, 6 ins. to I $\mathrm{ft}$.

(d.) Clayey green sand, olivecoloured, not so bright as above; green-coated flints resting evenly on chalk, $2 \mathrm{ft}$.

7. Wedge jointed, white; one or two bands of small flints about half-way down . ft.

The characteristics of the Eocene Beds of the district were here detailed by the writer. The London Clay, a stiff blue clay $30 \mathrm{ft}$. or more in thickness at Ipswich, has at Bramford been eroded until only 10 to $16 \mathrm{ft}$. of bedded brown and greenish-grey loam of the basement-bed remain, the whole deposit thinning out entirely less than a mile farther north. Fossils are very scarce, but occasionally pyritous casts of mollusca, wood and shells in cement stone, and pyritised plant remains are found. As a rule the fossils are so badly preserved as to be almost beyond determination, but among those identified are Pisania sp., Natica labellata Lam., Astarte sp., and Modiola sp.

In certain localities in the district (Messrs. Bolton and Laughlin's brickyard, and pits near Broom Hill brickyard) the top $20 \mathrm{ft}$. of the London Clay show evidence of having been subjected to immense pressure. Mr. Slater has shown (Proc. Geol. Assoc., vol. xxii (rgII), p. I I) that in place of the stiff blue homogeneous clay there has been developed a clay with a schistose structure much resembling the strain-slip-cleavage of older rocks. This fine schistosity was accompanied by glacial disturbance of the beds above the London Clay, and the more weathered, brown, disturbed part of the clay was separated from the horizontal bedded type by long thrust-planes.

The Oldhaven Pebble Bed is very persistent over the area and proves a useful datum line for mapping. Usually it is a sandy bed about I ft. thick, containing black flint pebbles, the larger ones up to 6 inches diameter being almost spheroidal, the smaller less well rounded. Exceptionally (see below) it is very shelly. As pointed out by Dr. Bassett in 19०3, the bed is referred variously in the Survey Memoirs to the basement-bed of the London Clay and to the Oldhaven Beds. In their lithological characters, the pebble-bed and the sands which often occur above it, separating it from the London Clay, resemble the Oldhaven Beds of the Thames Valley. The rapid thickening, sudden lithological change, the presence in places of small clay pebbles derived from the iron-mottled lenticular 
Proc. Geol. Assoc,, vol. XXIII.

Plate 32.

E.

w.

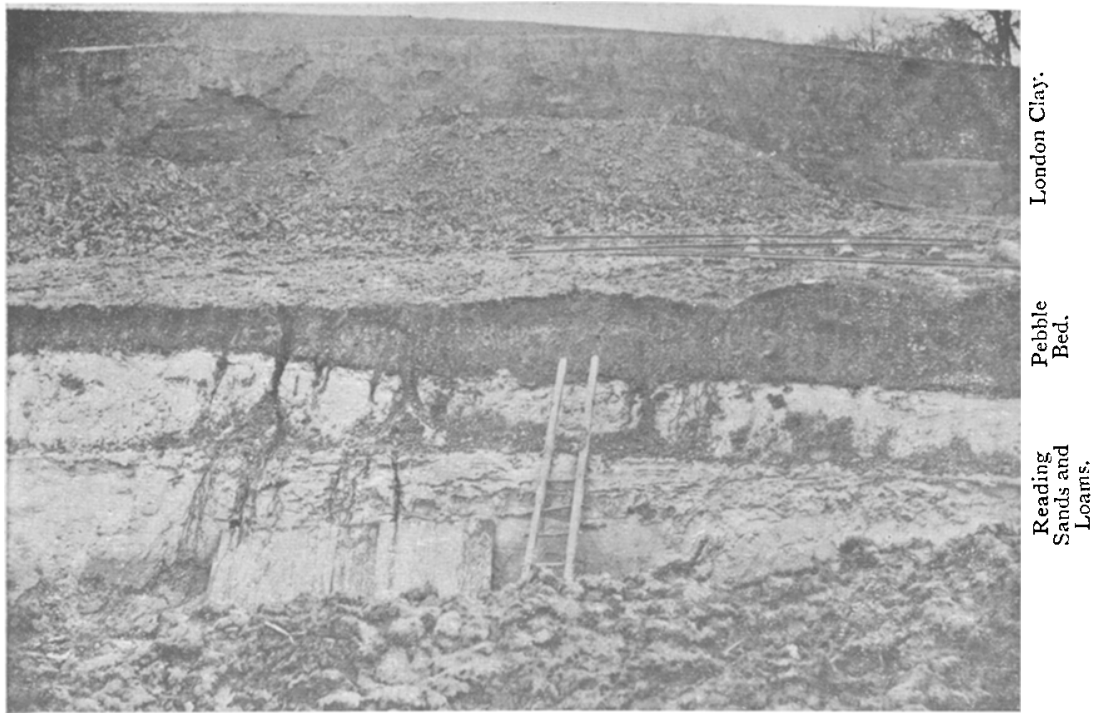

[Photo by G. Fillchanbets, Ipswich

A.-Eocene Beds at Bramford Brickyard, near II'swich.

N.

s.

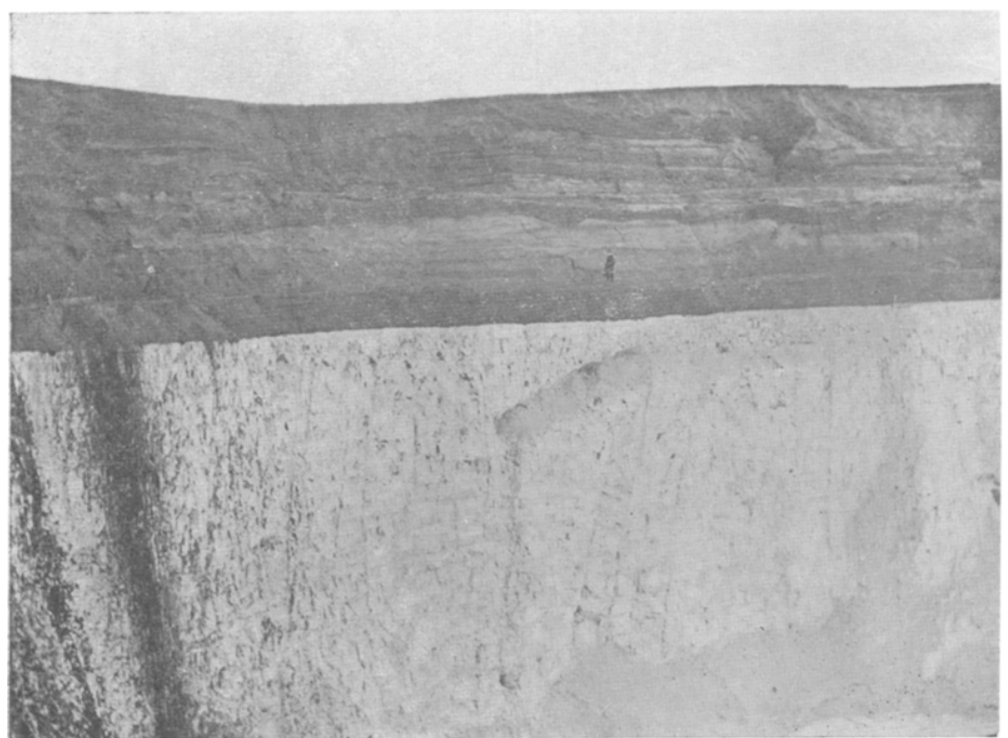

[Dhoto by G. Bellchambers, Ipswich.

B.-Section in a Chalk-Pit (CoE's) at Bramford, Near lpswich.

Glacial

Gravel.

Crag (?)

Sands.

Reading

Beds.

Thanet

Clay.

Chalk. 
clay masses of the Reading Beds below, and the sudden scooping down into the latter, indicate strong currents and disturbed conditions. An interesting case of contemporaneous erosion was to be seen in the brickyard north-west of Ipswich in I9ro, the sand above the pebble-bed cutting the latter off clean at about an angle of 30 degs., and resting directly upon the Reading sands below. Local upheaval must have caused denudation of the Reading sands and mottled clays, the latter giving rise to the great number of small clay pebbles in the Oldhaven Beds. A further interesting point brought out by mapping is the persistence of the outcrop of black flint pebbles for some distance to the north after the thinning off (by erosion) of the London Clay. The final disappearance of the pebble-bed with the Lower London Tertiaries on this northern margin of the London basin seems to imply its closer connection with them than with the London Clay. A note of an exposure which was to have been seen by the Association after tea comes more appropriately here. At one part of a brickyard near Ipswich (Messrs. Bolton and Laughlin's) rather an unusual facies of the Oldhaven Beds was to be seen. The section had been obscured for some years, but was opened up for this occasion, although the description given by Dr. Bassett in 1903 shows that the section is not now exactly as he saw it. Plate 33 illustrates the series of beds. The section now showing is as follows :

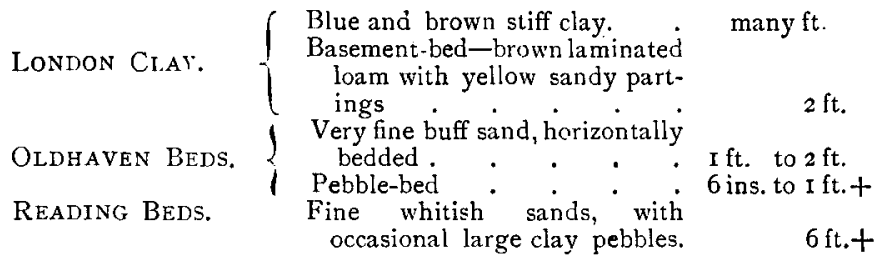

The pebble-bed is largely made up of small clay pebbles, many iron-mottled, of about I cm. diameter, of black flint pebbles, and fragile shells embedded in a light-coloured sand, round patches of which, clear of pebbles, are sometimes seen in the bed. Sharks' teeth are occasionally found, and the following is a list of fossils from the bed :

$\begin{array}{ll}\text { Astarte (tenera? and rugata?). } & \text { Aporrhais. } \\ \text { Cardium. } & \text { Natica labellata Lam. } \\ \text { Corbula. } & \text { Teeth of Odontaspis elegans Ag. } \\ \text { Cyrena. } & \text { O. macrota Ag. } \\ \text { Cytherea (? orbicularis). } & \text { O. cuspidata Ag. } \\ \text { Ostrea. } & \text { Lamna vincenti Winkler. } \\ \text { Pectunculus. } & \text { Teleostean vertebræ. }\end{array}$


(The above is Dr. Bassett's list, with additions from specimens kindly identified by Mr. H. A. Allen, of the Geological Museum, Jermyn Street.)

The shells are so fragile that it is almost hopeless to expect to extract any ; they must be hardened in situ, and then removed. The small list of fossils is sufficient to indicate that the fauna, like that of the London Clay of the district (see fossils noted above), has a marine facies, therein resembling that of the Oldhaven Beds of the Thames area.

Of the Thanet Beds exposed at the Bramford section, only two divisions, $a$ and $c$, call for special note. The top-portion here differs from the rest in appearance, but more particularly in containing here and there comparatively large grains of quartz ( 1 to $3 \mathrm{~mm}$. in diameter). Some are round, many are not but have their edges rounded, and they are all somewhat polished; occasionally they occur in pockets with, much less commonly, grains of other darker minerals. The yellowish clay $c$ passes laterally into a thinner band of tough clayey limestone of about the same colour. It weathers to quite a dirty white, and resembles impure septarian limestone. The Chalk is white, soft, and fairly dry, but has yielded up to the present no zonally determinative fossils. About $6 \mathrm{ft}$. from the top there occurs a band which occasionally yields shell fragments and pieces of Echinocorys test (apparently the large, rather rounded form of $E$. vulgaris of the zone of $B$. mucronata).

The party then visited the large chalk-pit, $1 / 4$ mile north of the brickyard (Plate $32 . \mathrm{B}$ ), where a fine section was to be seen.

Glacial Drift.

I. Gravel and sand, current-bedded, as before rests evenly on 2 .

ft.

CRAG (?)

2. Buff and brown sand with thin ferruginous layers; at base a gravelly layer, 6 ins. to I ft.,of flints and phosphatic nodules

READING BEDS. 5. Sand with lenticular masses of clay as above . . . .

THANET BeDs.

6. Rich deep green homogeneous clay at top for I ft. ; clayey green sand, grey clay, and green sand with green coated flints, $6 \mathrm{ft}$. .

Chalk. Resting evenly on 7. White Chalk

The gravelly layer at the base of 2 (? Crag) seems to have been formed from the break-up of the Oldhaven Pebble Bed on the Crag shore, as it consists largely of black flint pebbles and concretionary coprolites. A deceptive appearance has been caused by percolating water redepositing iron oxide, obtained from the Crag sand above, among the Reading sands (reaching in one place even to a clay bed), whose normal colour in the lower part near the Thanets is greenish or greyish. This has 
Proc. Geol. Assoc., vol. XXIII.

N.E.

8.w.

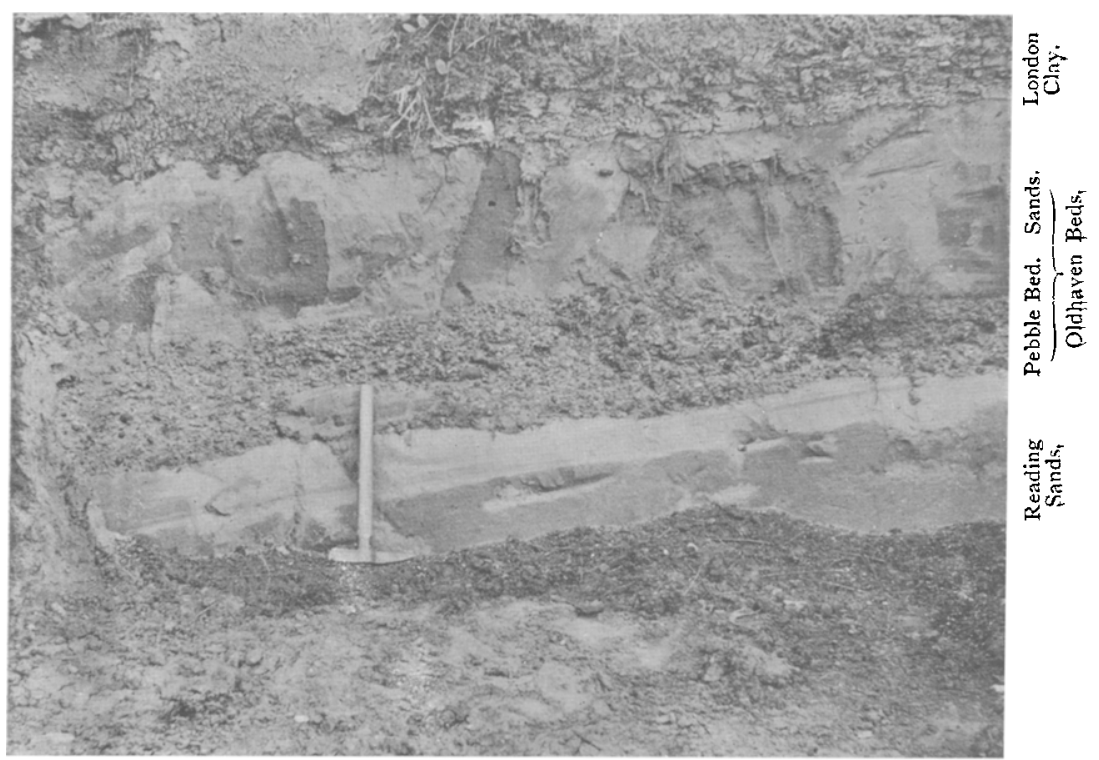

[Pr̃oto by P. G. H. Boswell.

Section in Eocene Beds at Messrs. Boiton and Laughlin's BRICKYARD, IPSWICH.

Showing unusual shelly conditions of the Oldhaven Pebble Bed. 
the effect of apparently considerably increasing the thickness of Crag sand. The water percolates down to the top of the Thanet Clays (the Reading loams not being persistent) and then issues as springs, descending as small falls over the chalk face, colouring it green, brown, and black, and forming alluvial cones at the base (see left of Plate 32.13). The Chalk as seen in the Gipping Valley pits is practically horizontally bedded (though often wedgelike), but the vertical jointing is somewhat irregular, in many cases departing considerably from the perpendicular (see right of Plate 32.B). There seems to be evidence also of some movement, faulting with small downthrow, and possibly slickensided vertical joint planes. Actually the Chalk itself (as determined from borings, etc.) dips in Suffolk about I $5 \mathrm{ft}$. to the mile east-south-east, and as the surface dips $10 \mathrm{ft}$. to the mile, this brings the successive zones to the surface as we proceed westwards across the county. In the eastern half of the county the Chalk is covered by a mantle of Eocene Beds, Crag

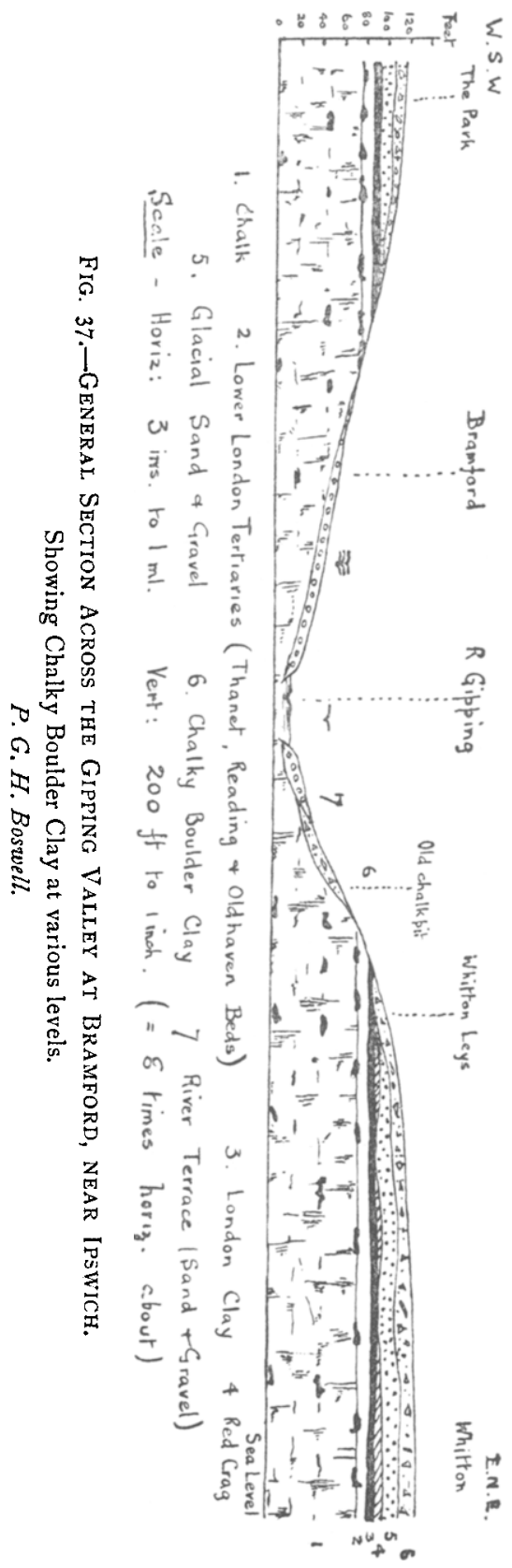


and Glacial drift, and is only seen where the larger valleys, such as the Gipping, are excavated through the covering of later beds. Fossils are not plentiful in the Bramiord Chalk, and, in the absence of better evidence, Mr. Jukes-Browne in I903 referred the whole of the Gipping Valley to the zone of Actinocamax quadratus. Many specimens, however, of Belemnitella mucronata have been obtained from the upper part of this pit, and the examples of Echinocorys vulgaris, obtained from a band about one-third of the way up, are, according to Dr. Rowe, rather characteristic of $B$. mucronata zone.* From the bottom $10 \mathrm{ft}$. of the pit a fair number of Actinocamax granulatus, and a few $A$. verus, as well as forms approaching $A$. quadratus, have been obtained. Thus the pit seems to show a capping of the zone of $B$. mucronata resting upon that of $A$. quadratus.

The members were able to spend a short time only in searching for fossils, and before leaving the pit the opportunity was. taken of obtaining a fine view of the Gipping Valley from the high ground at the top of the pit, and of discussing its age.

It was pointed out that the general watershed was to the northwest, the Chalk escarpment striking north-east and south-west, and that the Suffolk valley system was palmateror radiating in form. In each of the main valleys a deep channel filled with drift had been revealed by deep borings (that at Ipswich showing Chalk I Io ft. lower than normal-a drift-filled hollow), in each there was glacial disturbance of the beds where "bluffs" projected into the valley, and in each case the Chalky Boulder Clay wrapped quite down into the valleys from the plateau (examples. were pointed out close by where Chalky-Kimeridgian Boulder Clay lay successively on Glacial Sands, London Clay, Reading. Beds, and Chalk). Other reasons were given in addition to these, as showing clearly that the main contours of the district in preChalky Boulder Clay times, were much as they are now, and that the Gipping Valley, while necessarily post-Pliocene, is considerably older than the Upper Boulder Clay (see the Section, Fig. 37) + †

The "Glacial" gravels also appear in places to wrap down into the valleys. The river terrace of sand and gravel rests on the Boulder Clay in places, and its upper limit roughly follows the $5 \circ \mathrm{ft}$. contour (see map).

Returning to Grove House, the party was very kindly entertained to tea by Mr. and Mrs. Packard, and after a stroll round the beautiful grounds, hearty thanks were given to the host and hostess. Thanks were also rendered to the Directors, Excursion Secretary, and to the Ipswich Field Club for its welcome to the Association.

* I have to express my great indebtedness to Dr. Rowe for encouragement and direction, as well as help in determinations.-P. G. B.

+ Compare Mr. Hasmer's remarks on the Valleys of Central Norfolk, etc., in Igog and 1910 papers. 


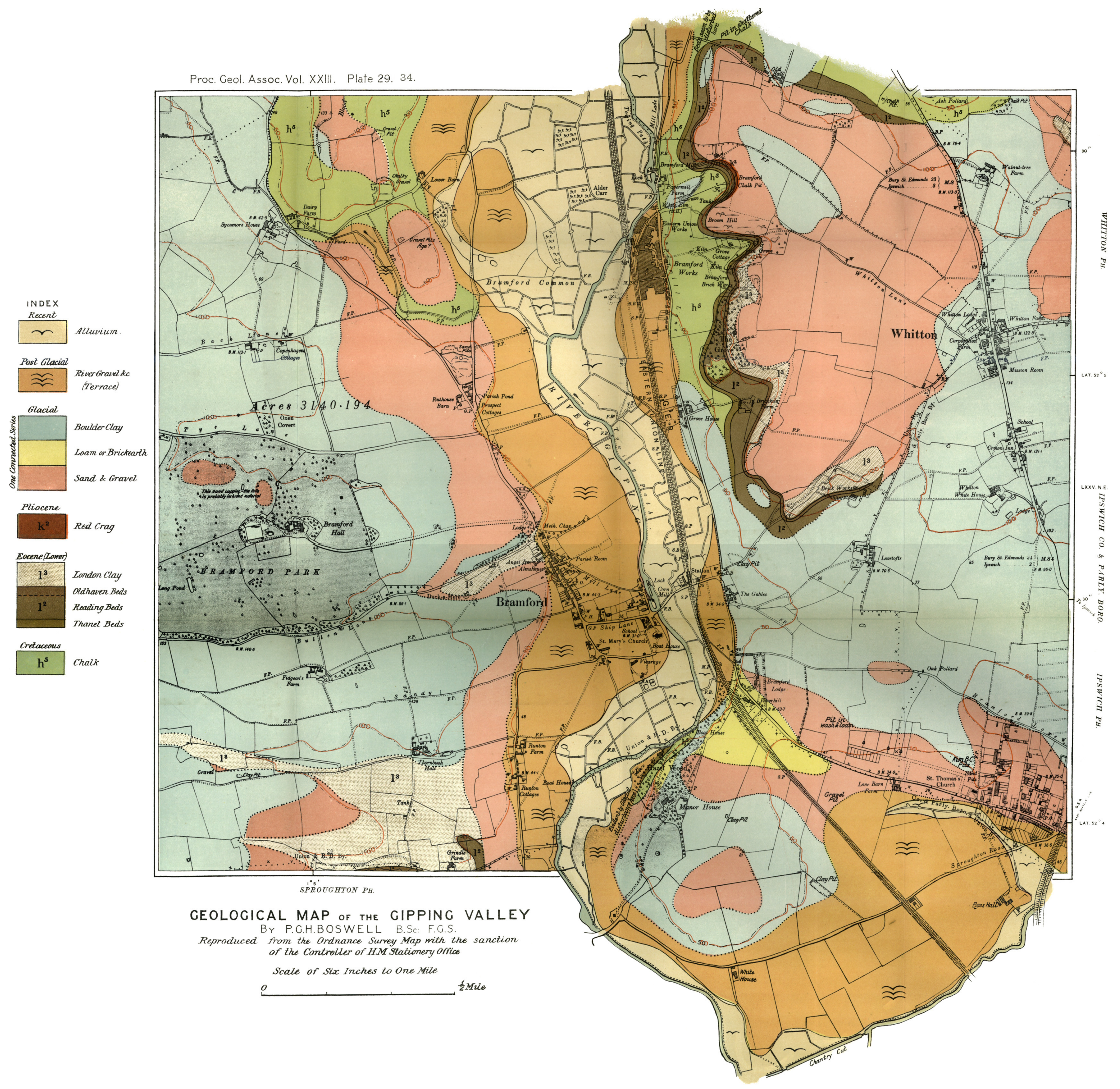


After tea the members returned by footpath to Whitton, passing, and briefly examining on the way, Whitton Leys Brickfield, where Boulder Clay was seen lying as a valley deposit on London Clay. The Oldhaven Pebble Bed and Reading sands were also visible. It was mentioned that this brickyard was one of the exposures of Eocene Beds described by Prestwich in his 1852 and 1854 papers on the Lower London Tertiaries, and by Sir J. B. Phear in 1854 .

Time did not allow visits to any more sections, and the party returned from Whitton by electric car to Ipswich Station, leaving by the 7.40 p.m. train for Liverpool Street. Mr. I. S. Double was the Excursion Secretary on this occasion.

\section{REFERENCES.}

Geological Survey Map, Old Series, Sheet 48 N.W.

1852. Prestwich, SiR J.-Quart. Fourn. Geol. Soc., vol. viii, p. 24r.

I854. - - Ibid., vol. x, p. 92.

I854. Phear, Sir. J. B.-"Geology of Gipping Valley, etc." Trans. Cambr. Phal. Soc.

I885. Whitakek, W., AND Dalton, W. H.- "Geology of Ipswich, etc." Mem. Geol. Su, v.

I903. BasseTt, H.-“Oldhaven Beds at Ipswich." Geol. Mag., o. 453.

I 903. Jukes-Brow'Ne, A. J.- "Zones of the Upper Chalk in Suffoik." Proc. Geol. Assoc, vol. xviii, p. 85 .

1907. Slater, G.-_Excursion to Ipswich and Claydon." Proc. Geol. Assie., vol. xx, p. I86.

I909. Harmer, F. W.-"Geology in the Field," Part I, p. 103. "Eastern Counties."

I910. - "Glacial Deposits of Norfolk and Suffolk." Trans. Norf. Nat. Soc., vol. ix, p. 108.

IgII. Sifter, G.-"Excursion to Ipswich." Proc. Geol. Assoc,, vol. xxii, p. II.

\section{REPORT OF AN EXCURSION TO CLAYGATE AND OXSHOTT, SURREY.}

Saturday, JUNe I 5TH, I9I2.

By Henry Dewey, F.G.S., of H.M. Geol.ogical Survey, Director of the Excursion.

THE party of fifty-two proceeded from Claygate Station to Messrs. Sims and Son's clay-pit at Oaken Lane. A view of the eastern face of the pit is given (Plate 35.A). Here the Director remarked that the primary object of the visit of the Association to this neighbourhood was the study of the Claygate Beds or the passage-beds between the London Clay and Bagshot Sands. 